\title{
Birhan Keskin Şiirinde Aşk ve Doğa: Halk Şiirinden Ekofeminist Şiire Doğru
}

\author{
Love and Nature in Birhan Keskin's Poetry: From Folk Poetry to Ecofeminist \\ Poetry
}

\section{HÜLYA ÇEVIRME*}

*Asst.Prof., Kocaeli University, The Faculty of Education, Umuttepe Campus, 41380, Izmit-Kocaeli, Turkey, E-mail: hulya.cevirme@kocaeli.edu.tr

(D) http://orcid.org/0000-0002-1779-7306

Öz: Bu çalışmanın amacı halk şiiri geleneği ile Birhan Keskin şiirinin akrabalı̆̆ıı aşk ve doğa izlekleri çerçevesinde metinlerarası bir okumayla sorgulamaktır. Sonuç olarak Birhan Keskin çağdaş bir şair olarak geleneksel olanı poetikasının güçlü bir kaynağı olarak benimsemiş, halk şiirinin animist/ mistik/ aşkın ve akışkan anlayışını çağdaş Türk şiirine eklemlemiştir. Keskin, Yunus Emre ve Karacaoğlan'la yüksek düzeyde metinlerarası bir söyleșim içindedir. Halk șiiri geleneğinin doğaya öykünme ve doğanın sağaltıcı gücüne sığınma izlek ve motiflerini, döngüsel tarih ve arkaik kadınlık mitiyle birleștirmiștir. Keskin, şiirinin metafiziğini Türkçe mistik şiir üzerinden var etmiş, romantik aşkı ve doğayı yeniden yüceltmiștir. Birhan Keskin kadim olanı tekrar etmekle kalmamış, Türk halk şiirinin hiyerarșisiyle modern karşıtlığı arasında, ekofeminist bir köprü kurmaya çalıșmıştır. Keskin'in geleneksel șiirle söyleșmesi kușkusuz șiirine doyumsuz bir kültürel derinlik, söylemine tanıdık bir dilsel kolaylık sağlamıștır. Keskin'in șiiri, Akışkan modern șiirin de halk şiirinden nasıl yararlanıldığın göstermek açısından şiirin kültürel belleği lehine yol açıcı olmuştur.

Anahtar kelimeler: Birhan Keskin, Yunus Emre, Karacaoğlan, Aşk, Ekofeminist şiir

Abstract: This purpose is to experience the relationship between folk poetry and Birhan Keskin's poetry, and to question the themes of nature through an intertextual reading. As a result, the poetry that Birhan Keskin will apply as a measure strongly embraced, the animist/mystic/transcendent/ liquid love, folk poetry and its poetry is closely connected to contemporary Turkish poetry. Keskin is in an intertextual conversation with Yunus Emre and Karacaoğlan, the two strongest collective subjects of folk poetry recording. It can be imported by extending the love poem and the theme it filters with references, and associations. As implementation based on the language of Yunus and Karacaoğlan, with an autobiographical introspection, is the self of love, of human, who gives visuals to nature, from society and from the system. She combined the themes and motifs of the folk recording of the imitation of nature and therapeutic book with the myth of natal history and archaic femininity. Keskin has experienced the metaphysics of his poetry in Turkish mystical poetry, his romantic love and nature have been eroded again. Birhan Keskin has done the ancient over and over again, working with the ecofeminist between the modern opposition of the Turkish people with a bridge. Our word about Keskin's discussion is to provide a linguistic convenience about an insatiable project, to be briefly explained. The people of Keskin's fluid modern poetry were also used.

Keywords: Birhan Keskin, Yunus Emre, Karacaoğlan, Love, Ecofeminist poetry 


\section{Giriş̧i $^{\mathrm{i}}$}

Şiirsel söylem önceki söylemlerden, metinlerden etkilenir, en azından ilham alır. Bu durumda her yeni şiirsel söylem, tarihsel ve kültürel edebi bir yansıma olarak metinlerarasıdır. Julia Kirsteva metinlerin alıntılar mozaiği olduğunu söylerken Roland Barthes başka metinlerin izlerinin yansıdı̆̆ bir prizma olarak tanımlar. Michael Riffaterre ise bunlara ek olarak okurun edincinin ve belleğinin metinlerarası boyutu etkilediğini belirtir. Gerard Genette ise metinlerarasılığı metin-ötesi bir eleştiri ilişkisine taşır ve metinlerarası ilişkinin metin dışı anlam dizgeleri ve kültürel kodları içerdiğini belirtir. Bakhtin'in belirlediği gibi bir söylem aslında bireylerarası bir toplumsal bağlamda gerçekleşir ve sözün çeşitliliği bireyin ve kolektif öznenin ideolojisinin izlerini taşır. ${ }^{1}$

Halk şiiri yaratıldığı tarihsel, toplumsal, ekonomik, sanatsal koşullar göze alındığında daha çok kolektif öznenin ürünü olarak değerlendirilebilir. Örneğin Yunus Emre şiirlerinin bütünüyle ona ait olup olmadığının bilinmemesi, yaşamı hakkındaki bilgilerin daha çok menkıbelere dayanması ve şiirlerinin halk arasında sözlü olarak yayılması onun şiirini sözlü geleneğin anonim karakterine daha yakın kılmaktadır. Karacaoğlan şiir geleneğinin ise bütünüyle anonimleşmiş olması, onun kimliğini ve şiirini daha da çok kolektif özneye dönüştürmektedir. Halk şiirinin bu kolektif boyutu, üreticisi ve tüketicisi arasında kültürel bir bellek oluşturur ve kuşaktan kuşağa aktarılır. Çağdaş bir şairde bu kültürel bellek bazen bilinçdışı bazen de bilinçli olarak varlığını sürdürür. Bu kültürel miras kimi şairlerin alımlamasını kolaylaştırdığı gibi şairin edebi kültürel mirasını tanımayan okuyucu için de zorlaştırıcı olabilir. Şiir çok anlaşılmak için bir okuma gerektirmese de şair- okur arasında uzlaşımsal bir alanda ancak daha bilinçli bir hazla okunabilir. Doğal bir zorunluluk olarak da okuyucunun metinlerarası okuma yapabilmesi nitelikli bir okumayı sağlar.

Birhan Keskin de halk şiiri geleneğinin kültürel belleğini bilinçli olarak çağdaş şiire taşıyan bir şairdir. O, bir konuşmasında; Karacaoğlan'ı şiirinin atalarından sayarak “...bir geleneğe bağlanacaksam halk şiirine akraba seçilmeyi isterim” der. Birhan Keskin'in kendisini halk şiirine akraba olarak görmesi onun şiirini metinlerarası bir okumaya açı olduğunu göstermektedir.

Birhan Keskin'in folklorun sanatsal ürünlerine yakınlığını farklı araştırmacılar da doğrulamaktadır. Birhan Keskin şiiri hakkında; gündelik halk dili, divan şiirinin ve tasavvuf düşüncesinin etkisi, dünya edebiyatının geleneksel imgeleri ve biçemleri, Yunus Emre ve Mevlâna Celaleddin- i Rumi duyarlılığı ${ }^{3}$ dile getirilmiş "Yüzünü eski zamanlarına dönmüş de yakınmalarını geçmişin dilini öykünerek değil, onun eskil anlamına inerek dile getirir gibidir..." kanısına varılmıştır. Emel Koşar Birhan

\footnotetext{
${ }^{i}$ Metin içindeki kısaltmalar: BK: Birhan Keskin; YE: Yunus Emre; KO: Karacaoğlan; MT: Mustafa Tatçı AŞE: Ahmet Şükrü Esen; KBB: Kim Bağışlayacak Beni; B: Ba; Y: Y’ol; SK: Soğuk Kazı; FK: Fakir Kene

${ }^{1}$ Kubilay Aktulum, Metinlerarası İlişkiler, Ankara: Öteki Yayınevi, 1999, s.1-91.

${ }^{2}$ Keskin ve Ustaoğlu “İyileştiren Şeyler'i Konuştu”, Evrensel, 24 Şubat 2017, erişim 6 Ekim 2021, https://www.evrensel.net/haber/309621/keskin-ve-ustaoglu-iyilestiren-seyleri-konustu.

3 Ahmet Tüzün ve Yüksel Büyükuysal (der.), Birhan Keskin Şiiri ve Ba-10. Altın Portakal Şiir Ödülü Sempozyumu, İstanbul: Metis Yayınları, 2008, s.67-68.

${ }^{4}$ Tüzün ve Büyükuysal, Birhan Keskin Şiiri, s.89.
} 
Keskin'in Soğuk Kazı adlı makalesinde şairin zamanı sorgularken halk kültüründen yararlandığını, ${ }^{5}$ Yılmaz ve Büyükarman ise nar meyvesinin Birhan Keskin şiirinde halk kültüründeki aşk, cinsellik ve haz çağrışımları çerçevesinde kullanıldı$\breve{g} 1 n 1^{6}$ belirtmişlerdir. Ancak Birhan Keskin şiiri, folklor bilimi, halk kültürü ve edebiyatıyla metinlerarasılık boyutunda söyleşimin amaçlı ilişkisi ve halk şiirinin çağdaş edebiyattaki sürekliliği henüz bütünlüklü bir incelenmeyi beklemektedir. $\mathrm{Bu}$ araştırma ise sadece Birhan Keskin'in halk şiiriyle olan akrabalığını belirlemeye katkı amacı taşımaktadır. Birhan Keskin'in şiirleri söyleşimde olduğu varsayılan, geleneğin en güçlü iki kolektif öznesi olarak da kabul edilebilen Yunus Emre, Karacaoğlan çerçevesinde incelendi. Çalışmada şiir metinleri karşılaştırmalı olarak ortaklık kurduğu varsayılan ve metinlerarasılığın bilinçli söyleşim kategorisine göre metinlerarası ilişkiler ${ }^{7}$ izlek, motif, metafor (eğretileme, mecaz), çağrışım, sezdirim ve göndermeler etrafında tartışıldı. Birhan Keskin'in Kim Bağışlayacak Beni (2012), Ba (2005), Y’ol (2006), Soğuk Kazı (2010), Fakir Kene (2016) adlı kitaplarındaki şiirler dize veya bölüt olarak alıntılandı ve metinlerarası bir okumayla yorumlandı. Yunus Emre'nin şiirleri Mustafa Tatçı'nın ${ }^{8}$, Karacaoğlan şiirleri ise Ahmet Şükrü Esen'in ${ }^{9}$ hazırlamış oldukları kaynaklardan alıntılanarak gösterildi.

\section{Aşk İzleği}

Halk şiiri dünyayı algılamak ve yeniden kurmak için ortak dil, düşünce ve algıla hareket eder. Halk kültüründeki izlekler, motif, sembol, eğretilemeler ise kuşaktan kuşağa bağlamsal durum içinde güncellenerek aktarılır. Bellekteki dilsel malzeme yan anlamlarıla birlikte somuttan soyuta veya soyuttan somuta geniş bir anlam ağı oluşturarak şiir söylemini oluşturur. Saussure'e göre ise dil toplumsal, bireyüstü bir soyutlamayken söz bireyseldir. ${ }^{10}$ Halk şairleri de dil ve söz arasındaki sözleşmeyi kültürel kodlarla üretmişlerdir. Örneğin; Karacaoğlan veya Yunus Emre dil ve söz arasındaki sözleşmeyi çok iyi kurduğu için günümüze gelebilmiş, Karacaoğlan, aşk ve doğa gerçekçiliğinin Yunus Emre ise tasavvuf dünyasında insanın yorumuna dair ortak kodların en güçlü kurucu kolektif özneleri olagelmiş, Birhan Keskin şiirinde de göreceğimiz gibi çağdaş şiire alt metin olarak ilham vermişlerdir. Bakhtin'e göre, sözce 'ben ve başkası' bağlamında ortaya çıkan bir üretimdir. Dolayısıyla, her sözce tek bir sesten değil, birçok sesten oluşur.

Bireyin dil biçemi ya da biçemleri başkalarının dil biçemleriyle girdikleri etkileşim içinde değerlendirilir. ${ }^{11}$ Birhan Keskin'in bu açıdan şiirinin çok seslilik boyutunun olduğu söylenebilir. Keskin'in halk şiiriyle olan akrabalığının bilincinde bir şair olarak metinlerarasılığın hem doğal hem de amaçlı kullanımına örnek oluşturmaktadır. Aşağıda Birhan Keskin şiirinin çok sesliliği, söyleşimde bulunduğu halk şiirleri etrafında, şiirsel olana analitik yaklaşmanın tehlikeleri de göz önünde bulundurularak daha çok sezgisel bir bağlamla yorumlandı.

\footnotetext{
${ }^{5}$ Emel Koşar, "Birhan Keskin'in 'Soğuk Kazısı”', Kültür Araştırmaları Dergisi, 1/3 (2019), s.371-378.

${ }^{6}$ Okan Yılmaz ve Didem Ardalı Büyükarman, “Birhan Keskin'in Şiirlerinde Birleşen, Taşan, Çoğalan Beden”, Motif Akademi Halkbilimi Dergisi, 13/32 (2020), s.1686.

${ }^{7}$ Cemal Sakallı, Günümüz Edebiyat ve Eleştiri Kuramları, Ankara: Anı Yayınları, 2016, s.53-58.

${ }^{8}$ Mustafa Tatçı, Yunus Emre Divanı, Ankara: Kültür Bakanlığı Yayınları, 1990.

${ }^{9}$ Ahmet Şükrü Esen, Anadolu Âşıkları-1: Karacaoğlan, haz., İsmail Görkem, İstanbul: Türkiye İş Bankası Kültür Yayınları, 2016.

${ }^{10}$ Mehmet Rıfat, Dilbilim ve Göstergebilimin Çağdaş Kuramları, İstanbul: Düzlem Yayınları, 1990, s.16.

${ }^{11}$ Şükriye Ruhi, Söylem Üzerine, haz., Ahmet Kocaman, Ankara: ODTÜ Yayınları (Metu Pres), 2003, s.23.
} 


\section{Yunus Emre/ Aşkın Aşk}

Günümüz düşünürlerinden Zygmunt Bauman, aşk ilişkisinin eski kalıcılığını ve sürekliliğini yitirdiğini belirterek bu anlamda aşkın değişen doğasını anlatmak için “akışkan aşk" terimini kullanır. Modern öncesi dünyaya ait eski ölümsüz aşk ve aşkın evrensel tarihinde mutlak olanı temsil eden hali için kullanılan "aşkın" terimini yineler. İçinde bulunduğumuz tarihsel süreç için ise, kimileri postmodern demektedir, Bauman buna akışkan modern $n^{12}$ der.

Türkçe mistik halk şiirinde aşk izleği tasavvuf düşüncesine bağl1, modern öncesi dünyaya ait aşkın/ mutlak aşkı temsil eder. Tasavvuf düşüncesinde aşk, Tanrı aşkı uğruna benliği feda etme, ruhu tevekkülle olgunlaştıran ${ }^{13}$ yaradılışla bütünleşmeye giden bir araç yoldur.

Yunus Emre'nin "Aşk ilinin haberin desem işide misin/ Yoldaş olup o yola sen bile gide misin” (MT, s.47) dizeleri ile Birhan Keskin'in "Sözde kalır sevgilim.../ Aşk çünkü, aşk çünkü kendine/ Bir yol, bir ideoloji ister" (Y, s.55) söylemi aşk yolunun bir ideoloji olduğu konusunda ortak görüşte olduklarını göstermektedir. Birhan Keskin'de de ifadesini bulan "Gerçekle değil, hakikatle değil./ Kalbimin aklıyla..." (Y, s.40) dizesi ise tasavvuf düşüncesinde gerçekliğin ancak kalple, gönülle kavranabileceği savının izdüşümü olarak okunabilir.

Tasavvuf düşüncesine göre aşk yoluna giren derviş kişinin dünyanın maddi boyutundan vazgeçmesi gerekir. Benliğini yok eden kişi ancak gerçek varlığa; Tanrı’ya ulaşabilir. Birhan Keskin'in "Yokluk ateşiyle tutunduk varlığa" (KBB, s.26), "etten geçip aşka varanın sevgisi/ Bunun yanında sevgilim bunun yanında etin ihaneti, klsaca hiçbir şeydir." (Y, s.25) dizeleriyle Yunus Emre'nin "Bu yokluk yolunda bize yoldaş olan kimdür" (MT, s.47), "Vuslat eri olan kişi gerek varlıktan mahvola" dizeleri arasında bu benzer bir söyleyiş ve anlayış çok açıtır.

Halk şiirinde aşk acısı; yanmak, kül olmak, yoluna baş koymak, kendinden geçmek, kanlı yaşlar akıtmak gibi ortak dilde kalıplaşmış söylemlerle dile getirilir. Birhan Keskin şiirinde bu söylemlerle karşılaşmak hiç de sürpriz değildir. Yunus Emre'de "Ben yürürüm yane yane/ Aşk boyadı beni kane", "Ben toprak oldum yoluna..." (MT, s.279) dizeleriyle Birhan Keskin'in şu dizeleri arasında kolayca koşutluklar kurulabilir. "Sen yanmak gör, ben kendimi kül ettim" (Y, s.70), "Yoluna baş koyup buzzzdaaaaa/ Kan kusanı." (Y, s.17).

Mistik halk şiirinde aşk acısı yücedir, aşkındır. “Âşık ışkun yükin çeker yücelerden yüce çıkar" dizeleri Birhan Keskin'de "Onu, sevebileceğinin en yücesiyle sevdin” (Y, s.38) dizelerini çağrıştırmaktadır.

Tasavvuf düşüncesinde dervişin aşk acısı artıkça Tanrı'ya daha çok yaklaşacağı düşüncesi hâkimdir. Yunus Emre'nin "Ah bu ışk elinden ah derd oldı dermen bana" (MT, s.29) dizesi, Keskin'in “Hiçbir şey yarama merhem olmasın” (Y, s.36), "Ruhumdaki sabır, kalbimdeki aşkla kurdum.../ Senin gördüğüm ağzımın kenarında duran dua, gözyaşına inandım/ ben ayaklarının altındaki toprağa, döktüğüm gözyaşına inandım" (SK, s.15) dizeleri arasında bu anlayışın izleri kolaylıkla görülebilir.

${ }^{12}$ Zygmunt Bauman, Akışkan Aşk / İnsan İlişkilerinin Kırılganlı̆̆ına Dair, çev., Işık Ergüden, İstanbul: Versus Kitap, 2012, s.14- 30.

${ }^{13}$ Recep Demir, Güzellik ve Așkın Şairi Şeyh Galip, İstanbul: Muhit Kitap, 2021, s.49. 
Sevgili uğruna tüketilen söz Yunus Emre'de ve Birhan Keskin'de yücedir. Yunus Emre'nin “Ayruk bize yas eylemez/ gönlümüzü pas eylemez/ Hak’tan gelen görklü avaz andan gelen ündür bana" (MT, s.25) dizelerinde yüce söz, gönlü de kirletmeyen sözdür. Birhan Keskin de şiirsel sözünü yüceltmekte, "Ben sözüme ruhumu verdim, yükseldi," (Y, s.70) demektedir.

Yunus Emre'de "Kaçanısa ölesiyem niçe bunda diri turam" (MT, s.221), "Ayaklara düşer Yunus bu yola baş olan kimdür” dizeleri uğuruna varlıktan geçilen, uğruna kendini feda eden, Fenafillâh anlayışı Birhan Keskin' de "Yoluna Baş koymak diyoruz / Biz barbarlar buna” (Y, s.19) olarak ifade edilmektedir.

Mistik aşkta dünyanın maddi varlığı, tenin ve benliğin maddi varlığı aşılmadan yüce olana ulaşılamaz. Keskin'in Denizkabuklusu şiirinde "Bu şehirde etten geçip kalbe erişene/ dek sabırla./ Tek, sabırla." (Y, s.29), Yunus Emre "Âşık öldi diye sala virrürler/ Ölen hayvan durur âşılklar ölmez" (MT, s.123) dizeleri ile "Can u tenden geçüben...", (s.186), "Işk yolına can fidi benüm gibi sad- hezar" (MT, s.43) "geçtim hepsinden, öyle hünerle ki yaşadığımı sanıyorlar hala" (KBB, s.75) dizeleri arasındaki örtüşme de çarpıcıdır. İki şair de aşk için kurdukları dünya yanında gerçek dünyayı küçümsemektedirler. Ancak kimi zaman acı iki şairde de katlanılmaz boyutlara ulaşır, bu durumda umutsuzluğa düşer isyan ederler. "Dost urdu yürege yara yaram onulmaz ne çare", "Esridi Yunus'un canı yoldayım illerim kanı/ Yunus düşte gördü seni sayru misın saglar mısın” (MT, s.279), "Dinü millet sorarısan âşıklara din ne hacet/ Asşık kişi harab olur âşık bilmez din diyanet", "Işsidürem sözini göremezem yüzini/ Yüzüini görmeklige canum viresüm gelür” (MT, s.63) gibi dizelerde Yunus Emre, Tanrìyı görme arzusunun gerçekleşmemesi sonucunda varl1ğından şüphe duyar. Her ne kadar tasavvuf düşüncesinde bu durum gerçek aşka; Tanrı'ya ulaşma yolunda bir aşama ise de âşık kişinin dinle olan ilişkisini anlatmak açısından, Yunus'un çağının sosyokültürel anlayışını aşan bu cesur duruşu, Keskin'i etkilemiş görünmektedir.

Tasavvuf düşüncesinde insan-1 kâmil olmak, insan olmanın son hedefidir. Buna “ölmeden evvel ölmek” denilmektedir. "Ben zaten o ilk acıyla ölmediğime çok gücenmiştim hayata./ Insan olmuştum ilk o zaman./ Ya da bozmuşlardı beni yenidoğandan." (Y, s.21), "Bir Küçük iyiliktir aşk/ Değil mi ki, billurdan bir yalan dünya/ Bırak ersin o tamama" (s.33) söylemiyle Yunus Emre ise "Gönül pasın yudunısa kibr ü kini kodunısa” (MT, s.41) söylemiyle insan olmanın kibirden, kinden ve kötü kalplilikten uzak durmaktan geçtiği düşüncesinde birleşirler. Her iki şair de aşkın ve acısının insanlaşmaya ve iyiliğe katkı sağladığını savunmaktadırlar.

Birhan Keskin'de âşık, mutlak bir aşkla arınmış masum ve yüce insandır. “Dünyanın işine karışmadım/ beni avutmaz dünya, beni tutmaz da dolanıp içinde kirinin/ yine temiz geldim.” (KBB, s.67). Keskin, Aşk şiirinde (B, s.29) “'yukarı ăgdım', 'ayak'landım', Dünyayı dolduran sözü olduran o./ Hala soruyor musun bana aşk ne demek:/ O en 'bir' ve 'tam' olana yürümek” (B, s.29), “Bir cümledir insan/ arşla ferş arasında ve hep haklı/vardım işte demek için/ ömür denen cisimde saklı” (Y, s.71) gibi dizelerinde varlığın birliği ilkesine aşkla varılacağı düşüncesine göndermelerde bulunur. Bu göndermelerin de Yunus'la söyleștiği de açıtır. Keskin'in insan ve aşk hakkında geliştirdiği etik ve estetik tasavvuf düşüncesiyle de söyleşim içindedir. Bu söyleşim Keskin şiirinin metafiziğini de kurumuştur. Keskin Yunus'la söyleştiğini "Hepsi bir gurbet duygusu gibi/...Dünya başıma yıkıldı uyandım bir/ Bir kabul ettim Yunus ilinde." (SK, s.36) dizelerinde açı yüreklilikle dile getirmektedir. 


\section{Karacaoğlan/ Akışkan Aşk}

Aşk izleğine dair kolektif, yani kültürel dil ve anlayış profan (din dışı) halk şiirinde somut bir özneye yöneliktir, örneğin gördüğü her güzele arzu duyabilen Karacaoğlan'ın aşkı maddecidir ve buna bağlı olarak da akışkandır. Karacaoğlan aşkı, sevgiden cinselliğe varan geniş bir karşı cins betimlemesiyle çoğu kez erotik bir boyutta anlatır. "Çeziver sevdiğim göğsün düğmesin/ Tomurcuk memeler sevilsin bugün” (AŞE, s.129), "Nerde güzel görsen orda kalırsın.../ Her gün bir güzelle yatmak istersin” (AŞE, s.241) dizelerinde görüldüğü gibi Karacaoğlan Türkçe'nin en cesur şairidir. Birhan Keskin, Karacaoğlan'ın cinselliği açıkça anlatan bu tarz söylemlerini “...Bilebildiğim tüm modern şiirimiz boyunca Karacaoğlan samimiyetiyle 'meme' demiş bir tane şairimiz yok ki. Karacaoğlan o dönemde söylüyor, ama biz makaslayarak şarkı yapabiliyoruz." 14 takdir ederken onu şiirinin atası olarak da ilan eder.

Karacaoğlan erkeğin biyolojik doğasını, Birhan Keskin ise kadının biyolojik doğasını yazmaktadır, "Dürtme içimdeki narl/ Üstümde beyaz gömlek var" (B, s.24) derken, "inanmak istesem de/ senin gidişin yalandır bende" (KBB, s.65), "Dön/erken sen önce ayaklarının gerçekliğine inandır beni” (Y. s.43) söyleminde olduğu gibi Karacaoğlan gibi sevgilinin somut varlığını ister gibidir. Ancak Keskin çoğu zaman aşkın gerçekliği karşısında idealisttir. $\mathrm{O}$ ancak ayrılığın acısına katlanırken kendisini teselli etmek için gerçeği fark eder gibidir ancak ardından yine "sonsuz aşk" mitine geri döner. "Hiçbir aşk titremez sonsuza değin Bütünlüğünü yitirişinden ölür bir mum/ ve insan acıdan ölür bir gün” (B, s.104) der.

Karacaoğlan ise pragmatiktir. Sevdiği çok uzaksa "Aramız ıraktı seni unuttum" (AŞE, s.208) diyebilir veya sevgisine karşıllk vermeyene iyi davranmayabilir. Sevgiliye ulaşmaya gücü yetmezse vazgeçebilir. "Karac'oğlan derki nasıl beğ imiş/ Üst yanımız karlı karlı dă̆ imiş/ yokladım öteni öten yoğ imiş/ Kız almam ben seni huri isen de" (AŞE, s.98). "Kıza iyi de gelin kötü diyemem/ İkiniz de benimsiniz sunalar" (AŞE, s.159) dizelerinde söylediği gibi duygu ve düşüncelerini çok açık bir dille ifade eden Karacaoğlan sevdiğine şiddet de gösterilebilir: “... hasbağçadan gonca güller biçmedim/ Fırsat elde iken alıp kaçmadım" (AŞE, s.234). "Seni el deymedik güller sandım/ Yâd ile konuşmuşsun bir zaman” (AŞE, s.315) dizesinde olduğu gibi cinsiyetin toplumsal kategorilerine göre düşünür ve davranır.

Keskin şiirinin öznesi hem kendisine hem de âşık olduğuna "kadın" demektedir. Taş Parçaları (Y, s.13-55) adlı şiir iki kadın arasındaki aşk anlatılmaktadır. "Yüzüm:/ :(dağlı Leyla, kar kiriği”" (B, s.21), "Anladım bir kadına düşerse ışık nehirlere fisıldayan.../ Çok şey hissediyorum senin için/ Ama değil bunlar senin istediğin” (B, s.43), "Ben hala sarllyım beline senin.../ She left home" /B, s.9). Gibi birçok dizede olduğu gibi cinsel kimliğin özgürce ifade edilmesinde Keskin şiiri Karacaoğlan şiirinin erotik cesaretini de aşmaktadır.

\section{Dikey / Yatay Aşk}

Geleneksel ve feodal toplum, tasavvuf düşüncesinde olduğu gibi aşk1, özü olgunlaştırmanın, nefsi terbiye etmenin bir yolu olarak yüceltmiştir. Bu yüceltmenin so-

\footnotetext{
${ }^{14}$ Ezel Keskin, “Gününden Beri Hem Kadın Hem Şair”, Sabah Gazetesi, 4 Nisan 2010, erişim 1 Mart 2021, https://www.sabah.com.tr/pazar/roportaj/2010/04/04/keskin_ezel_gununden_beri_hem_kadin_hem_sair
} 
nucu olarak âşık, sevgilinin yanında olma pahasına otoritesini kabullenir. Bu kabulleniş ise çile çekmeyi, sevgilini zulmünü kabulde gönüllü olmayı yani dikey bir ilişkiyi betimler. Halk şiirinde âşık; kul, köle sıfatlarıyla tanımlanırken sevilen ise maşuk, sultan, şah olarak isimlendirme, bu dikey ilişkinin gösterenlerine işaret ederler. Gelenekte âşık, maşukun her türlü cefasına veya şiddetine hoşgörülü yaklaşır çoğu zaman. Yunus Emre "Bana bu 'ş̧k tolalı adum Yunus olalı/'Iyan oldı padişah kulam şükrane geldim” (MT, s.186) ve Karacaoğlan "El bağlayıp divanına durayım/ Kız kapında kulun kölen olayım" (AŞE, s.93), "Karac'oğlan kapunuzda kul gibi/ Gönül küstü̈̆̈̈ yerde ince kıl gibi”, (AŞE, s.189) gibi dizeler dikey iletişimin görünümlerini sunmaktadır.

Keskin'in "Kalbimden ayă̆ınaydı yolum/...söktüm senindir, sana bağışladım/ ağaran saçımı, senindir, al." (DK, s.34-35), "Getir hatıranı, ko gelsin o da ben senin hatıranı öpüp başıma” (SK, s.31) gibi dizelerde halk şiirindeki dikey ilişkiyi benzer dil ve anlayışı da çağrıştırmıyor değildir. Ancak bu dikeylik halk şiiri geleneğinin abartılı dili gibi, aslında, "sevgili uğruna her şeye katlanmak" durumunu idealize etme ve aşkı aşkın bir boyuta taşıma gayreti olarak yorumlanabilir.

Halk şiiri aşkta adaleti ve eşitliği de savunur kimi zaman; "Herkeslere sevdiceği verilsin/ Bir kaşı karaya eş eyle beni” (AŞE, s.205) "Ĕ̆er dostum gönlün bana yoğ ise Benim işim minnet ilen zor değil” gibi dizelerde Karacaoğlan aşkta demokratik tutum sergilemekte eşitini, dengini istemektedir.

Modern aşk ilişkisinde romantik yüceltme, âşık olunanı daha çok yoldaş veya müttefik olarak görme biçimine dönüşmüştür. Bu açıdan da modern ilişkide ben'in değeri eski ben ve sen ilişkisine göre daha demokratik bir varoluştadır. Kendisi ve diğeri ile ilişkisinde sosyal maskeleri yerine bedel ödeyerek de olsa, toplumun korunaklı ilişki kalıpları yerine daha az güvende olan aşk $1{ }^{15}$ tercih etmesi açısından Birhan Keskin'in âşık öznelerinin cinsel kimliklerinin kadın oluşu yatay bir aşk ilişkisini de göstermektedir. Birhan Keskin' de "Bir barbar ancak eşitine dokunur" demekle aşkta adil olmaya işaret etmektedir. "Ben canım esirgemem yar senden/ Götür sat pazara kölem var diyü” (AŞE, s.131), "Kul olayım gözleriyin hepine” (AŞE, s.315) diyen Karacaoğlan'a karşılık, Keskin “Artık her şey tüccarların elinde” (SK, s.32) dizesi ise çağının dikey ilişkilerini belirleyen ideoloji de karşı çıkmaktır. "Ben senin kötü olduğunu, senin kötü olduğunu/ Anlamamak için çok çalıştım/... Benim seninle ilgili bildiğim her şey yaland1... Tersinden bir adaletsizliği.../ Ben bunun için bir Afrikalı gibi çalıştım” (SK, s.19) söyleminde geleneksel aşk ilişkisinin "kul, köle" söylemindeki dikey çağrışımları üzerinden aşırı modern dünyanın akışkan ilişkilerine göndermede bulunur gibidir.

\section{Barbar / Medeni}

Birhan Keskin âşık özneyi ve ona benzer insanları "Barbar” sözcügüyle niteler. Soğuk Kazi'da (s.17); Jospi şiirinde "Bu dünyada insan dediğin ikiye ayrılır jospi/ Bir: Ayrilıktan sonra hiçbir şey olmamış gibi/ Davranan medeniler; Bir: Atlarına davranan/ Barbarlar", "Her şeyden öte öyle sevdim ki ben seni / Yoluna Baş koymak diyoruz / Biz barbarlar buna" (Y, s.19), "Fazla insansin sevgilim sen fazla insan / Bir barbarım ben oysa, bir hayvan / Dilim bă̆ışlamaktan söz eder benim / Seninki adalet ve intikam" (Y, s.48) gibi dizelerinden okunduğu gibi Keskin'de barbar olan; aşkına bağlı, adil, zulmetmeyen, inanan, unutmayan, bağışlayan, ihanet etmeyen,

${ }^{15}$ Karl Mannheim, Kültür Sosyolojisi, çev., Mustafa Yalçınkaya, İstanbul: Pinhan Yayıncılık, 2017. 
sevmekten vazgeçmen, kirlenmemiş inan- âşı̆̆ın belirtenleridir. Yunus Emre ise yaban, hayvan; “ışk olmayan bellü bilün yabandadur" (MT, s.83) dizesinden anlaşıldığı gibi gerçek aşkın Tanrı aşkı olduğunu bilmeyen, nefsini terbiye edemeyenin belirtenidir. Anadolu ağızlarında yaban, taşra, yerleşimin olmayan yer anlamlarında kullanılır. Benzer kullanım Yunus Emre'de görülmektedir, "Yaban yolın gözetme yol evde taşra gitme" (MT, s.55) demektedir. Yunus Emre'nin hayvan, yaban imgelerinin tersten bir işlevle, çelişik anlamda da olsa çağrıştıran Birhan Keskin'in bu kullanımı dar anlamda sevgiliye yönelik bir sistem, eleştiri geniş anlamda ise çağın akışkan insanına yapılan bir eleştiri olarak okunabilir. Karacaoğlan'a göre ise "On beşinde yavrı güzel sevmeyen/ Dünyasına hayvan gelmiş bön gider" (AŞE, s.458).

\section{Kader / Felek}

Geleneksel şiirde âşık sevdiği uğruna her şeyi göze alabilir ancak gücünün ve aklının yetmediği durumlarda inançlarına sığınır ve kaderine boyun eğer. Tanrı buyruğu ve felek karşısında halk şiiri kimi zaman teslimiyetçidir, bazen de kaderine karşı çıkar, "felek", "talih" dediğine karşı koyar, şikâyet ve sitemlerinde suçlamaya kadar gider.

"Pek göresim geldi o hilal kaşı/ Zalım felek tuzak kurmuş salmıyor" (AŞE, s.500), "Hemen kara yazın bana mı felek" (AŞE, s.22), "Sen benim olsan da vermem feleğe" (AŞE, s.173), "Niydeyim tutan var yollarımızı/ ...Kıyamete yakasından tutarım" (AŞE, s.172) dizelerinde Karacaoğlan'ın kaderine hem boyun eğme hem de karşı durma tutumları görülmektedir. Benzer durum Birhan Keskin'in Taş Parçaları (Y, s.13-55) adlı şiir iki kadın arasındaki aşk anlatılmaktadır. Şiir aynı evde yaşamak ve yaşlanmak, evi yuva yapmak sözü veya hayalini yıkan "Sen" e seslenmektedir. "Ey Adalet'ten söz eden zalim" sözleriyle betimlenen sevgiliyle dünyanın hali arasında zalim ve yalancı olma açısından benzerlik kurulmuş, sevilen ve dünya yarg1lanmış ancak sonuçta bütün yaşananları "O senin ezel gününden kaderin” ifadesiyle kader kabul etmiş ve sabırla kabullenmiştir.

\section{Dünya}

Dünya, halk şiirinde olduğu gibi, Birhan Keskin için de aşkla anlamlı ve güzel ve katlanılasıdır. Yunus dünyaya “...dost için kılalum zarı" (MT, s.169) söylemiyle katlanır ve dünyayı "Bu dünya bir gelindür yeşil kızıl donanmış/ Kişi yeni geline bakuban toyamaz" (MT, s.116) dizeleriyle betimler. Birhan Keskin ise dünya ağrısına, sevilenle bir ömür geçirme hayali için katlanır. "Serin bir rüyanın hatırınadır çektiğim dünya ăgrısı/ Mavi-yeşil bir hatıra: işte dünya/ ruhum! İște dünya ağrısı işte dünya kederi.../ ağrı ve kendini tamamla" (KBB, s.13) dizeleri yine Yunus'un üsteki dizelerini çağrıştırmaktadır. Birhan Keskin "kalbimdeki aşkla kurdum.../Ovada ve dağda saklı bir mavi için düştüm yola" dizelerinde dünya aşk için yola çıkılan yerken, Yunus Emre'nin “Ariflere bu dünya hayal ü düş gibidür/ Kendüyi sana viren hayal ü düşten geçer” (MT, s.87) dizelerinde Tanrı’ya ulaşma yolunda beklenilen geçici bir yerdir.

Yunus Emre’nin “Bu dünya kahır evidür/ niçe ömürler eridür” (MT, s.163) dizelerinde Karacaoğlan'ın "Bu dünyada gülmek nasip olmadi” (AŞE, s.244), "Git yalan dünya da senden usandım” (AŞE, s.245). "Ben bu dünyaya geldim geleli/ Daha neler gelecek başıma benim/ Eğer nazlı yar da benim olmazsa/ Bakın gözümün yaşına 
benim" (AŞE, s.277) dizelerinde olduğu gibi dünya aşkla yaşanılasıdır. Yoksa istenenin elde edilmediği durumlarda, mutlu olunmayan, zalim ve geçici bir yerdir.

Birhan Keskin benzer bir anlatımla "Madem dünya bunca zalim, Madem yakışmıyor kalbimize Telleri kopsun sazların, bütün davullar vursun" (Y, s.13) "Yalan dünya, içimde zulmün duvarları" (Y, s.15), "Dünyada iki kapılı bir han gibi durmanın” (Y, s.34) dizelerinde dünyayı halk şiirinden farklı anlatmaz.

\section{Taş Dağ}

Taş motifi halk şiiri geleneğinde, somut veya soyut, olumsuzluk durumunun belirtenidir. Yunus Emre'de taş aşksız, idraksiz, Tanrı'yı bilmeyen yaban olanın belirtenidir. "Işıısuzlara benüm sözüm benzer bellü kayaya/ Bir zerre 'ş̧ olmayan bellü bilün yabandadur" (MT, s.83), "Dertsüzlere benüm sözüm benzer kaya yankusina" (MT, s.363). "Ben toprak oldum yoluna sen aşuru gözedürsin/ şu karşuma göğüs gerüp taş bagırlutaglar mısın" (MT, s.279) dizelerinde ise onun acımasızlı̆̆ını ifade eder. Karacaoğlan ise "Bağrıma basarım taşlar/ Akıttım gözümden yaşlar/ Yavrusunu aldıran kuşlar/ Yuvasına döner gelir" (AŞE, s.490), "Taşlar alıp kara bağrım döğeyim", "Vara vara vardım ol kara taşa/ Hasret ettin beni kavim kardaşa" gibi Türkçe’nin kalıplaşmış diliyle sevgiliye ulaşamamanın verdiği üzüntü, gurbet duygusunu, ayrılık, acımasızlık kısacası iletişimsizlik durumlarını anlatır.

Birhan Keskin' de taş motifi imgeleşerek anlam genişlemesine uğrar ve imgeleşir. Söylenemeyen söz, acı, acımasızlık, sabır, öfke, değişmezlik, süreklilik ve aşk yükünü taşıyamamak anlamlarında kullanılır. "Sen beni tek/ tek/ tek bıraktın. / Benim artık taş taşıyacak,/ Taş kaldıracak, taş atacak halim mi var!" , Fiyort şiirinde (B, s.34). "Taş ki durandı yalnızca", "Doğrudur taşımın çatladığı”, "Taş sakladım ben yıllarca taşta/ Bu yüzden anlamıyorsun öfkem nasıl sert/ Nasıl taze, nasıl bozulmadı taşıdığım taş/ Ağır bir taşla yaşadım nasıl/ Beni esirgeyen taşı da öyle söküldü sab$\mathrm{rım} /$ Nasıl benzedim taşa, ya da taş bana/ bilemezsin" (FK, s.48) dizelerinde taş imgesi âşık insanın ve dünya hallerini anlatırken "Kum ve Kayaç benim/ Taş taşıdım, içim kendimden yorgun benim, dilim çok uzun Yankı./ En eskisiyim ben buranın" (B, s.35) dizelerinde ise kadim olan insan ve dünyayı da temsil eder.

\section{Dağ}

Halk şiiri geleneğinde dağ motifi, somut ve soyut anlamlarıyla, şiir öznesinin ulaşımına engel olan veya yollarını bağlayan, açan, aşılması zor olan ancak ardında istenen yerin, yârin olduğu doğa parçasıdır. Yunus Emre'de dağ "Ben toprak oldum yoluna sen aşuru gözedürsin/ şu karşuma göğüs gerüp taş bagırlu taglar mısın/ Ben Yarümden ayrı düşütüm sen yollarımı bağlar mısın" (MT, s.279) söylemiyle Tanrı'ya ulaşmayı hem engelleyen hem de kolaylaştıran çift anlamlı bir motiftir.

Karacaoğlan'da dağ motifi "Yine dumanla(n)dı dağların başı /Didemden akıttım kan ile yaşı” (AŞE, s.500), "Dağ salına konan kervan/ Yağmur yağar gerilenir/ Bir kötüye düşen dilber ölmez ama zarilenir" (AŞE, s.492). "Bir ah çeksen yüce dağlar delinir" (AŞE, s.71), "Yıkılası aramızda dağlar var" (AŞE, s.442) benzer anlamlara gelir.

Keskin'de ise diğer motifler gibi dağ motifi de genişler ve imgeleşir. “Dă̆ susmaya giden yolu biliyor" (KBB, s.21), "İki yanım dağ, üşüdüm heybetinden”, (KBB, s.22), "Yolları yarları yılları geçtim/ ters döndüm taştım düşü̈m/ Yollar tamamlar mı beni/ Uzakta solgun yüzüm, hasreti sakinim/dağ gibi sever beni, dağ gibi suskunum/ 
bu yüzden ben en çok dağlara baktım/ tamamlanmadım/ tamamlanmadım" (KBB, s.68) dizelerinde olduğu gibi dağ motifi halk şiirindeki anlamlarıly birlikte suskunluğun ve öfkenin de belirteni olarak anlamca genişler.

Yol

Halk şiirinde yol motifi de kalıplaşmış sözlerle karşımıza çıkar ve yaşamla ölüm arasındaki süreç, sevgiliye ulaşma çabası ile geçen acı dolu ömür, sırlar taşıyan sonu ölümlü bir yürüyüş, bazen de gaflet içerisinde geçirilmiş bir yaşamın metaforu olur. Gerçek anlamıyla da sılaya veya sevgiliye isteğine kavuşturan veya uzaklaştırandır. Coğrafi uzaklık, konar ya da göçer olma, farklı din veya mezhepten olma, sınıf farklılığı veya egemenin gücü aşkı imkânsız kılar. Ya da aradaki rakip yüzünden âşık hep gurbettedir.

Yunus Emre "Dirlik budur Ma’şukyolında öle” (MT, s.397), “Taştın yine deli gönül sular gibi çağlar mısın/ Akdun yine kanlu yaşum yollarımu balar mısın” (MT, s.278) dizelerinde olduğu gibi hem gerçek anlamıyla yol hem de metaforik anlamıyla birlikte Tanrı'ya olan serzeniş ve sitemlerini, ona ulaşamamanın acısını anlatırken "Karac'oğlan düşse yola/ Yar dediğin temür kale/ Ya alınır ya alınmaz" (AŞE, s.361), "Tıfil (i)ken sevdi Karac'oğlan seni/Yoluna koymuşum can ile seri/ Nice terk eyledin ben gibi yâri” (AŞE, s.362) hem metaforik hem de gerçek anlamlarıyla kullanır. Benzer kullanımı Keskin de sürdürür.

Halk şiirinde sevgilinin bulunduğu yere "il” denir. Yunus Emre, "Oldum ilümden avare.../...yoldayım illerim kanı" (MT, s.279) derken Karacaoğlan, “Gurbet ilde yari olan yiğidin" (AŞE, s.110), "Dost ilinden bade içtim" (AŞE, s.187), "Kendim gurbet ile dahil olunca/ gelenden haberim al melilmeli" (AŞE, s.237) der. Keskin ise Kırık Anafor şiirinde "gürültüyle konuşuyorsun/ Aşağı iller/ Susmuşşimdi/ Oyy'sa" (B, s.20), “... aşağı illermişim eskiden” (B, s.25) dizeleriyle hem Yunus hem de Karacaoğlan'la söyleşir. "Yolları yarları yılları geçtim...ters döndüm taştım düşü̈m./ Yollar tamamlar mı beni" (KBB, s.68) dizelerinde olduğu gibi Keskin yol ve anlam evrenindeki sözcükleri; yolcu, göç, göçebe, yaban gibi sözcükleri gelenekteki metaforlarını daha da biyografik hale getirerek tüm anlamlarıyla kullanmayı sürdürür.

\section{Aşkın Doğa}

Arkaik ontolojide insan doğayla bütünleşiktir. Eliade'ye göre; arkaik dünyada her türlü yaşantı, avcılıktan cinselliğe kadar her eylem kutsal olana katılmaktır. Bu durum yaşantıyı ritüele dönüştürür ve hiçbir eylemin amacı rasyonel akılla açıklanmaz. Örneğin binlerce taşın içinde birinin anlam içermesi ve kutsal taş olması ilk mitsel eylemleri anlatmasının sembolü olmasındandır. Bu nedenle asıl gerçeklik şeyleri yaratan ve sürdüren bu tözdür ve bu yüzden kutsal ve ölümsüzdürler. Arkaik ontolojide zaman ve doğa döngüseldir ve tarihsel zamanın ilerleme mitine karşı tekrara ve arketiplere dayanır ${ }^{16}$. Bu döngüsel zaman doğayı taklit eder, dünya aynı anda eşsüremsel ve artsüremsel bir bütünlük olarak kavranır. ${ }^{17}$ Birhan Keskin'in “En eskisiyim buranın./Issızlık bilgisiyim ben/... Tekrar tekrar gördüm.../ Büyük zaman, benim” (B, s.35) dizeleri zamanın döngüsel algılanışı olarak okunabilir.

Yolcu ve Aça'ya göre de “Türk geleneksel dünya görüşünü besleyen ana perspektiflerden biri de animizm, totemizm ve Şamanizm kaynaklı mitolojik-arkaik bir doğa

\footnotetext{
${ }^{16}$ Mircea Eliade, Ebedi Dönüş Mitosu, çev., Ümit Altuğ, Ankara: İmge Kitabevi, 1994, s.154.

${ }^{17}$ Claude Levi Strasuss, Yaban Düşünce, çev., Tahsin Yücel, İstanbul: Yapı Kredi Yayınları, 1994, s.306.
} 
bilgisidir. Bu bağlamda, Türk folklorunun en eski formlarında canlılar dünyası ile insan arasında keskin bir hiyerarşinin kabul edilmediği ve bundan hareketle doğakültür karşıtlığı olgusunun yerine doğa-kültür bütünlüğünün görünür kılındiğı söylenebilir." 18 Birhan Keskin, varlığ bu dünya görüşünün, animist düşüncenin perspektifinden de duyumsar. Y'ol adlı kitabında (s.73), "Siz 'It was very amazing' derken 'and fun'/ Onlar özür dileyenlerdi ağacın ruhundan" dizesinde animist toplulukların avdan sonra öldürülen hayvanın ruhundan özür dileme ritüeline göndermede bulunur. Keskin'in "siz" dediği uygar, medeni kabul edilen insanını "Onlar" ise "öteki”nin temsilidir. "Öteki” cahil, yoksul, barbardır (Y, s.73). Bu şiirde öteki yani yabanıl olan yüceltilmektedir.

Tasavvufi halk şiiri de arkaik ontolojinin izlerini taşımaktadır. "Elest benüm ilümdür Elest benüm yolumdur/ Ezel ile Elest’i ben bunda göre geldüm” (MT, s.185), "Ben ezelden varıdum ma’şukıla yarıdum” (MT, s.186), "Ezeli bilişidük birliğe yitmiş idük" (MT, s.50) söylemi döngüsel bütünselliği taşır. Birhan Keskin ise "O senin ezel gününden kaderin” (Y, s.35) derken varlığını ve zamanı döngüsel algılar.

Tasavvuf düşüncesinde evrendeki her şey gibi doğa da Tanrı'nın tezahürleridir. Yunus'un "Gideridüm ben yola sıra yavlak uzamış bir ağaç/ Böyle latif böyle şirin gönlüm eydür birkaç sır aç” (MT, s.38). "akup deniz olursın tagılıp toz olursın/ göllerde saz olursın yapılan evler senün" (MT, s.157) dizelerinde anlattığı gibi gerçekten sırlar, işaretler taşır ve birbirine dönüşür, her şey zıddıyla var olur. İnsan bu işaretlerin ve zıtların birliğini duyumsadıkça görünenin ardındaki gerçeğe yani Tanrı'ya yaklaşır. Yunus'ta da halk şiiri geleneğinde de doğa öykünme ve arınmayı sağlar.

Keskin, Yunus'ta da yaradılışın tözleri olan su, hava, toprak ve ateşin anlam evrenini genişleterek kullanır. "Taşın sabrı, suyun ruhuyla büyüttün beni/ bundandır her gittiğimde aklımda kalmak fikri”. Birhan Keskin için dört temel unsur şiirinin hem içerik hem de biçemini düzenler. Birhan Keskin'de "rüzgâr, sana karıştım/ seninle değiştim kendimi/ üstüme sardiğın bu uğultulu örtü/ gizlemiyor yine de/ bir zamanlar derinime işleyen vahşeti" dizelerinde anlattığ gibi doğa benzer şekilde mimesis ve katarsisin uzamı olarak aşkındır.

Arkaik dünyada zaman insan hayvansallığın masum ve belleksiz günahsızlığındadır. ${ }^{19}$ Yunus Emre'nin "Kalü beli didük evvelki demde / Dahı bugündür ol dem ü bu sa'at" (MT, s.37), dizeleri dünyanın yaratılmadığ 1 ruhların toplandığı yer Kalu Bela ile Birhan Keskin'de sevgiliyle ilk birlikte olunan ilk gün arasında çağrışım kurmak mümkün. Benzer duyumsama ve söylem Birhan Keskin'de yabanın tarihe katlanması hep o ilke, kayıp cennete, altın çağa dönme isteğinin hatırınadır. Birhan Keskin arkaik belleğine olan özlemi ömrünün masumiyet çağlarına ilk olana, evvel olana dönüş isteği benliğinin kirlenmemiş çocukluğuna duyulan özlemi anlatır. At şiirinde "akşamları eski bir ninniye koysunlardı başlarını" (s.20), "İçimde elmanın dişlenişi”" (s.31), "Sana sarılmış kalmış ilk günüm ben/..." (B, s.9) gibi dizeleri Birhan Keskin şiir öznesinin kurduğu döngüsel kozmos kutsar. Keskin tıpkı arkaik dünya insanının büyük olayları kutsal ritlere çevirmesi ve tekrar etmesi gibi o da aşkı ve doğayı kutsal, yüce, aşkın, döngüsel bir ontolojiyle anlatır. "Ve aşkta ölü-

${ }^{18}$ Mehmet A. Yolcu ve Mehmet Aça, “Geleneksel Ekolojik Bilgi ve Folklor”, Folklor/Edebiyat, 25 /100 (2019), s.866.

${ }^{19}$ Eliade, Ebedi Dönüş Mitosu, s.92-94. 
mün bir anlamı vardır, görklü kılınan” (Y, s.49). "Döndüğüm, döndüğüm ama döndüğ̈̈m/ Döndüğ̈̈m bu sema sensin” (Y, s.34) der.

\section{Doğaya Sığınma}

Halk şiiri duygu ve düşünceyi açıklamak veya betimlemek için doğanın hallerinden yararlanır. Doğa sevincinin veya kederinin göstereni olarak insanın yoldaşı ve sığınağıdır. Doğanın varlığından ve türlü türlü hallerinden etkilenen şairler doğa ile özdeşim de kurarlar.

Yalçın Olgun türkülerden hareket ederek Türk kültür ekolojisinde, doğayla duygudaşlık kurma ve onunla bütünleşme duyarlılığının olduğunu ${ }^{20}$ söylemektedir. $\mathrm{Bu}$ duyarlılık ancak modern şiirden sonra da ekolojik bir ideolojiye dönüşmüştür. Kuşkusuz halk şiirinde doğanın insana verdikleri maddi boyutuyla değerli bulunmuş, kimi zaman manevi bir boyutta doğa kutsanmıştır. Bu kutsamanın kökeninde mitik dönemler ve animist inançların izleri de görülebilir. Örneğin Yunus Emre doğadan aldığı güçle aşkın zorluklarını aşar "Tagları yirinden trar yol eyler dosta gitmeye", "Ab-ı hayat çeşmesi âşıkların visalidür/ Kadehi tolu yüridür susamışları yakmaga”, "Kendüliginden geçeni togan idinür ma'şukl/ Ördek ü keklige salar sürü idüben tutmağga" (MT, s.17).

Karacaoğlan'da doğa her şeyiyle mutluluğunun gösterenidir. Dağa sığınılır, yol aşılır, turnalar haber getirir. Baharda sevgiliye ulaşılır. "Lale sümbül bir araya gelince/ Kız oğlana nergis verir gül verir/Aşıp aşıp gelir yayla belinden”, "Sakla Çiçek Dağı kaşı karamı" (AŞE, s.442), "Dost' (i)le yaylayacak zamanın dağlar" (AŞE, s.432), "Güzel gelir bahar ile yaz ile/ Gölün dolar ördek ile kaz ile" dizelerindeki doğa motiflerini Birhan Keskin de tekrar eder; “... telli turnalar, arada/ neşeli yağmur” (B, s.15) dizesi "Gllavuz gönderdim telli turnayı” (AŞE, s.118).

Keskin “Dünyaya tortullar, tabakalar, yarlar gerektir/ İçerde çok yanmışa dışarda karlar gerektir." (SK, s.11), "Sen dünya mülkündesin, öyle!... / Sen yanmak gör, ben kendimi kül ettim" (Y, s.70) der ancak ardından "Sen bu alçaklıkta dur, ben otlara gittim" (Y, s.70) söyleminde dünya mülkünü terk ediş sözünden, uygarlığın yarattığı alçaklıklardan kaçarak doğaya yaban doğaya sığınmayı ve onda sağalmayı ister. “Taşın sabrı, suyun ruhuyla büyüttün beni/ bundandır her gittiğimde aklımda kalmak fikri” (SK, s.17) dizelerinde doğanın tözleri onu iyileştirir. Keskin doğanın sonsuzluğu, ölümsüzlüğü ile aşkın ölümsüzlüğü arasında varoluşsal olarak iyileştirir. "Su ve rüzgâr, dă̆ ve doruk,/ Sonsuz hepsi," (B, s.29) derken o aşktan, insandan ve varoluşundan kaynaklanan acılara sabırla ve inatla katlanmasını doğadan öğrenir. "Aşkın da sabrı vardır/... Bağla atını söğ̈̈dün gölgesine/ taştığı yerde aklın/ ota bak, çimene, dur” (Y, s.69) derken yaşamın yorgunluğunu da dindirir. Doğa halk şiirinde olduğu gibi şairin duygu durumuna yoldaşlık da eder. "Terliymiş mavi gök bıkkınmış akşamüstü/... sardunya daha şımaracakmış." (KBB, s.18). "ruhum! Ovada sert es, yamaçta sus, / trmakta ağla/... ister dağın gölgesinde dur, ister/ incirin neşesine vur/ağr kendini ve tamamla" (KBB, s.13) dizelerinden anlaşıldı̆̆ gibi doğa Keskin'in parçalanış benliği bütünleştirir.

\section{Ekofeminist Şiire Doğru}

Ekoşiir (ekopoetry) bir arka plan olarak doğayı anlatan pastoral şiirden veya şairin

\footnotetext{
${ }^{20}$ Yalçın Olgun, "Türk Kültürü Sözlü Şiirinde Ekolojik Boyut: Derin Ekoloji Yaklaşımı Bağlamında EkoEleştirel Çözümleme", Folklor/Edebiyat, 26/103 (2020), s.463-482.
} 
duygu ve düşüncesini daha kolay ve etkili anlatmak için hallerinden yararlandığg bir işlev dışında günümüzün ekolojik kaygılarını ideolojik bir mücadeleye dönüştürmeyi amaçlan şiirdir. Ekoşiir kimi zaman feminizmle iş birliği yaparak insanın ve diğer canlıların birbirleriyle ve çevreleriyle olan ilişkilerinde doğal ve sosyal sistemlerin ilişkisini irdeler. ${ }^{21} \mathrm{Bu}$ şiir kadının kültürün yapay ve insanlıktan uzak hallerini değiştireceğine dair motifi sıklıkla tekrar eder ve tarih dışı ötekine, dişil olana karşı bir nostaljiyi edebiyatının temel izleği olarak dile getirir. Dişiliğin tarih öncesi zamanlara, Âdem ile Hava'nın Cennetten kovulmadığı önceki zaman ve doğaya ve animist kültürün Doğa Ana, Kadim anne mitine dönüşü sıklıkla dillendirir. ${ }^{22}$

Çağdaş Türk şiirinde, Birhan Keskin bu şiirin müjdeleyicisi olarak "Sen beni kızını çok seven bir anne olarak hatırla" (Y, s.46), "Beni kızımdan kardeşimden etmişlerdi/ Kanatlandığım yol, indiğim vadi/ Hiç bitmedi çıtığım göç bir daha” (SK, s.13) gibi dizeleriyle doğa ana mitine göz kırpar.

Ekofeminist şiir, modern öncesi organik insanın ve doğanın döngüsel ritmiyle kadını özdeşleştirir. Birhan Keskin'in “...en eskisiyim buranın/ Karnıyım dünyanın. Yeryüzünün ağrısı bendedir. / Issızlık bilgisiyim ben/...Tekrar tekrar gördüm.../ Büyük zaman, benim.” (B, s.35) dizelerinden okunacağı gibi şiirin öznesini bu kadim anlayışla anlatır. Keskin, Atlar şiirinde (Y, s.60) “...Dünyada biz onlarla rüzgâr gibiydik,... Onların burada olmaması./ Otların sesinin uzak durması da demek bundan" dizeleri ise henüz insanın belki de cinsel kimliklere bölünmediği zamanlara olan özlemi dile getirirken bu eksikliği "Kuru nehir, kadim ağrı" (B, s.15), "Bir şaman burada, bir şaman davuluna/ Sabah olana dek kayının kederiyle vuruyor" (B, s.25) dizeleriyle anlatır. Çağdaş insan ve erkeğin artık sahip olmadığı o eski tamlığın karşısına kendi kendine yeten bütün kadını şiirin öznesine dönüştürür. " $D a l$ kırılmamışken, kök kendine küsmemişken/ Her kesin yuvası doğrulduğu yerdeyken henüz/...Öyle saf, öyle saf/ Yarılmamışken, bir yanımız öbürüyle dururken" (SK, s.54-55). "Sararan yaprağın zehri benmişim / Ve meğer buzulun orjini”" (SK, s.33) dizelerinde henüz bölünmemiş insan ve doğanın ritmini bulmaya çalışır.

Birhan Keskin insanın doğaya etiklerine karşı hüzün içerisindedir. "Eski bir sanrtdır yıldızlı göğün altında yaşadığımız" (SK, s.43), "Sultan Sazlı̆̆ı'nda boynu eğri bir kuşun / ince boynuna yediği kurşun gibi hainiz hepimiz” (SK, s.17) dizelerinde Karacaoğlan'ın "Boynun eğri zülüflerin bozgundur" (AŞE, s.485) dizesini de göndermede bulunarak okuyucuyu o kadim tamlıktan ve mutluluktan alıp çă̆ının acımasızlığına getirir. Keskin uygar insanın, dünyayı yaşanmaz hale getiren, doğayı yok etme uğraşısına karşın ilkelin, yabanın doğa duyarlılığını yüceltir. "Onlar özür dileyenlerdi ă̆acın ruhundan" dizesi bu duyarlılı̆̆ının en çarpıcı dizesidir. "Arkamda dağlar yitirmişim, ufkumda denizleri/ Beraber uyuyup beraber uyandiğımız hayvanlarımızı yitirmişim/... Ayaklarıma yeşil otlar değmişti, üstümden beyaz bulutlu gökyüzü yürümüştü (B, s.41). "Sen bu alçaklıkta dur, ben otlara gittim" (Y, s.70) dizelerinde yine bugünün yapaylığından yabana, doğaya sığındığı görülmektedir. "Bana kırların tekdüze, ovanın rutin, nehrin durgun,/ arada sıçrayan yerini bağışla./ Tekrar./ Bir zamanlar vardı...” (Y, s.59). "Şemsiye sözcüğ̈̈ yokken, henüz yapraklar varken" (SK, s.54). "Çağımın aklında plastik çiçekler" (KBB, s.9), "Yăgmur da sevmiyor artık bizi/ Eski bahçe acı çekiyor benim yerime" dizelerinde ise

${ }^{21}$ Meliz Ergin ve Özen Nergis Dolcerocca, “Edebiyata Ekoeleştirel Yaklaşımlar: Ekoşiir ve Elif Sofya”, Selçuk Üniversitesi Edebiyat Fakültesi Dergisi, 36 (2016), s.297-314.

${ }^{22}$ Rita Felski, Modernitenin Cinsiyeti, çev., Atalay Gündüz, İstanbul: Dergah Yayınları, 2020, s.61-98. 
Keskin doğa- kültür karşıtlığını ironik bir dil ve ekolojik bir duyarlılıkla anlatır.

Birhan Keskin şirininin ekofeminist karakteri özellikle Soğuk Kazı ve Fakir Kene’de daha baskın görünmekle birlikte diğer şiir kitaplarında bu karakter daha çok halk şiiriyle söyleşerek, arkaik doğayı kutsal, yüce, aşkın bir ontolojik anlayışı içinde ele alır. Bu iki kitabında daha çok politik gündemi takip eder ve kadını, erkeği ve doğayı geleneğin ve sistemin eril şiddetinin yansıması içinde kara mizahın diliyle anlatır. "İste öyle Allah’ım bilirsin çok güzel yapmışsın bu yeryüzünü. / Bizim köyler gibi. Allah'ım bunlar tokileri seviyor, betonları, hizl trenleri." (FK, s.25) “Âdem var ve onun kaburgası filan.../ Çömelmek: Törelerimiz böyleydi ben istemezdim filan.../ Onlar koca onlar baba onlar sevgili onlar devlet/ Eşitlik istediğimizi sananlar yanılıyor/ Kim eşitlenmek ister hırsızlar ve katillerle Birhan!" (FK, s.37) gibi dizelerinde diğer kitaplarına göre halk şiirinin estetiğinden daha uzak gündelik bir dil ama daha ekofeminist bir duruşla anlatır.

\section{Sonuç}

Birhan Keskin aşk ve doğa izleklerini, halk kültürü ve ona bağlı halk şiirinin izlek ve motifleriyle takip etmiş, şiir dilini, gelenekten süzdügü çağrışım ve göndermeler yoluyla eskiden yeniye doğru genişletmiş, söylemini kristalize etmiştir. Keskin aşk ve doğa izlekleri hakkında geliştirdiği dil, etik ve estetik, halk şiiri geleneğin en güçlü ve cesur iki kolektif öznesi; Yunus Emre ve Karacaoğlan'la yüksek düzeyde metinlerarası bir söyleşim içindedir. Aşktan, doğaya zarar veren insandan, toplumdan ve sistemden incinmiş bir benliği, otobiyografik bir iç dökmeyle onların dilinden ve gönlünden anlatır.

Birhan Keskin şiirinin temel gerilimi iki kadın arasında yaşanmış, ayrılıkla sonlanmış, aşk acısından doğar. Keskin'in şiir öznesi hala bu aşk içinde, ayrılık acısına alışmaya, katlanmaya çalışırken hem kendisiyle hem de "sen" dediğiyle hesaplaşır. O bu aşk acısını, kadının doğasına ve doğaya henüz yabancılaşmadığı tarih öncesi arkaik benliğiyle dindirmeye çalışsa da kadim doğanın ve kültürün yokluğu onu trajedisine yenilmiş mağrur bir kadına dönüştürür. Bu nedenle onun şiir öznesi, barbar bir göçebedir ve bu çağın aşk ve doğa anlayışına yabancıdır. Gerçek yerleşik ve ölümsüz olan aşk ve doğadır. Öyleyse aşk ve doğa yücedir, iyidir, sağaltıcıdır. Âşık özne ise günün akışkan halinden arınmış bir özne olarak yücedir. Keskin İnsan ruhunun aşk ve doğa bütünleşmesine duyulan özlemini animizm, tasavvuf düşüncesi ve halk şiiriyle besleyerek anlatır. Keskin halk şiiri geleneğinin doğaya öykünme ve doğanın sağaltıcı gücüne sığınma izleklerini aşırı modern şiire taşımış ve onları kadınlık mitiyle ekolojik bir şiire dönüştürmüştür.

Birhan Keskin romantik aşkı eski katmanlarından alarak "sonsuz aşk" izleğiyle bugüne taşımıştır. Şiirinin metafiziğini Türkçe mistik şiir üzerinden var etmiş Türk halk şiirinin gündelik halk dilini kullanma geleneğini ise özellikle âşılk insan, cinselliğin estetize edilişi ve pastoral doğaya duyulan nostalji, doğanın sağaltıcı gücüne sığınma boyutunu anlatırken yoğunlaşmıştır. O, eskiyi tekrar etmiş, Türk halk şiirinin hiyerarşisine uymuş buna ek olarak da antropolojik bir çıkış olarak, kadının doğada güçlü olduğu zamanlara özlem veya dönüşle ekofeminist bir anlayış arasında iyileştirici, onarıcı bir köprü kurmaya çalışmıştır. Ekolojik kaygılarını, feminizmle iş birliği yaparak, kadın kültürünün yapay ve insanlıktan uzak halini değiştireceğine dair düşünceyi; tarih dışı ötekine, dişil olana karşı bir nostaljiyle dile getirmiştir. Keskin'in şiirini gelenekselin üzerinde inşa ederken halk şiirinin aşk ve 
doğaya ait eril dilini daha çoğulcu bir kimlikle "akışkan modern” bir şiir iklimine çevirmiştir.

Onun şiirinin öznesi Tanrı yolunda çile çeken bir derviş gibi hep yoldadır ve kaderine boyun eğmiş, ondan arınarak yücelmiş epik bir kahraman gibi, ağır bir kederle, gidenin ardından çağdaş bir ağıt yakmaktadır. Keskin'in bu tarihsel bilinçte, geleneksel şiirle söyleşmesi kuşkusuz şiirine doyumsuz bir kültürel derinlik katmıştır. Diğer açıdan söylemine tanıdık bir dilsel kolaylık sağlamış, akışkan modern şiirin de halk kültüründen ve şiirinden nasıl yararlandığını göstermek açısından kültürel bellek lehine de yol açıcı olmuştur.

\section{Kaynakça}

Aktulum, Kubilay. Metinlerarası İlişkiler. Ankara: Öteki Yayınevi, 1999.

Bauman, Zygmund. Akışkan Aşk/ İnsan İlişkilerinin Kırılganlığına Dair. Çev., Işık Ergüden. İstanbul: Versus Kitap, 2012.

Demir, Recep. Güzellik ve Aşkın Şairi Şeyh Galip. İstanbul: Muhit Kitap, 2021.

Eliade, Mircea. Ebedi Dönüş Mitosu. Çev., Ümit Altun. İstanbul: İmge Kitabevi, 1994.

Ergin, Meliz ve Özen Nergis Dolcerocca. "Edebiyata Ekoeleştirel Yaklaşımlar: Ekoşiir ve Elif Sofya”. Selçuk Üniversitesi Edebiyat Fakültesi Dergisi. 36 (2016): 297-314.

Esen, Ahmet Şükrü. Anadolu Âşıkları-1: Karacaoğlan. Haz., İsmail Görkem. İstanbul: Türkiye İş Bankası Kültür Yayınları, 2016.

Felski, Rita. Modernitenin Cinsiyeti. Çev., Atalay Gündüz. İstanbul: Dergâh Yayınları, 2020.

Keskin, Ezel. "Gününden Beri Hem Kadın Hem Şair”. Sabah. 4 Nisan 2010. Erişim 6 Ekim 2021. https://www.sabah.com.tr/ekler/pazar/roportaj/2010/04/04/ keskin_ezel_gununden_beri_hem_kadin_hem_sair.

“Keskin ve Ustaoğlu 'İyileştiren Şeyler’i Konuştu”. Evrensel. 24 Şubat 2017. Erişim 6 Ekim 2021. https://www.evrensel.net/haber/309621/keskin-ve-ustaogluiyilestiren-seyleri-konustu.

Koşar, Emel. "Birhan Keskin’in 'Soğuk Kazısı'”. Kültür Araştırmaları Dergisi. 1/3 (2019): 371-378.

Levi Claude, Strauss. Yaban Düşünce. Çev., Tahsin Yücel. İstanbul: Yapı Kredi Yayınlar1, 1994.

Manheim, Karl. Kültür Sosyolojisi. Çev., Mustafa Yalçınkaya. İstanbul: Pinhan Yayıncilık, 2017.

Rıfat, Mehmet. Dilbilim ve Göstergebilimin Çă̆daş Kuramları. İstanbul: Düzlem Yayınları, 1990.

Ruhi, Şükriye. Söylem Üzerine. Haz., Ahmet Kocaman. Ankara: ODTÜ Yayınları (Metu Pres), 2003.

Sakallı, Cemal. Günümüz Edebiyat ve Eleştiri Kuramları. Ankara: An Yayınları, 2016.

Tatçı, Mustafa. Yunus Emre Divanı. Ankara: Kültür Bakanlığı Yayınları, 1990.

Tüzün, Ahmet ve Yüksel Büyükuysal (haz.). Birhan Keskin Şiiri ve Ba-10. Altın Portakal Şiir Ödülü Sempozyumu. İstanbul: Metis Yayınları, 2008. 
Yalçın, Olgun. "Türk Kültürü Sözlü Şiirinde Ekolojik Boyut: Derin Ekoloji Yaklaşımı Bağlamında Eko-Eleştirel Çözümleme". Folklor/Edebiyat. 26/103 (2020): 463-482.

Yılmaz, Okan ve Didem Ardalı Büyükarman. "Birhan Keskin'in Şiirlerinde Birleşen, Taşan, Çoğalan Beden”. Motif Akademi Halkbilimi Dergisi. 13/ 32 (2020): 1675-1689.

Yolcu, A. Mehmet ve Mehmet Aça. "Geleneksel Ekolojik Bilgi ve Folklor". Folklor/Edebiyat. 25 /100 (2019): 861-871. 